\title{
Cell proliferation, cell shape, and microtubule and cellulose microfibril organization of tobacco BY-2 cells are not altered by exposure to near weightlessness in space
}

\author{
Björn J. Sieberer · Henk Kieft • \\ Tiny Franssen-Verheijen · Anne Mie C. Emons • \\ Jan W. Vos
}

Received: 4 March 2009/Accepted: 13 August 2009/Published online: 16 September 2009

(C) The Author(s) 2009. This article is published with open access at Springerlink.com

\begin{abstract}
The microtubule cytoskeleton and the cell wall both play key roles in plant cell growth and division, determining the plant's final stature. At near weightlessness, tubulin polymerizes into microtubules in vitro, but these microtubules do not self-organize in the ordered patterns observed at $1 g$. Likewise, at near weightlessness cortical microtubules in protoplasts have difficulty organizing into parallel arrays, which are required for proper plant cell elongation. However, intact plants do grow in space and therefore should have a normally functioning microtubule cytoskeleton. Since the main difference between protoplasts and plant cells in a tissue is the presence of a cell wall, we studied single, but walled, tobacco BY-2 suspension-cultured cells during an 8-day spaceflight experiment on board of the Soyuz capsule and the International Space Station during the $12 \mathrm{~S}$ mission (March-April 2006). We show that the cortical microtubule density, ordering and orientation in isolated walled plant cells are unaffected by near weightlessness, as are the orientation of the cellulose microfibrils, cell proliferation,
\end{abstract}

B. J. Sieberer · H. Kieft · T. Franssen-Verheijen .

A. M. C. Emons · J. W. Vos ( $\square)$

Laboratory of Plant Cell Biology, Wageningen University, Droevendaalsesteeg 1, 6708 PB Wageningen, The Netherlands

e-mail: janw.vos@wur.nl

\section{A. M. C. Emons}

Department of Biomolecular Systems, FOM Institute for Atomic and Molecular Physics, Science Park 113,

1098 SG Amsterdam, The Netherlands

Present Address:

B. J. Sieberer

Laboratoire des Interactions Plantes Micro-organismes, UMR

INRA-CNRS 2594/441, 31320 Castanet-Tolosan, France and cell shape. Likely, tissue organization is not essential for the organization of these structures in space. When combined with the fact that many recovering protoplasts have an aberrant cortical microtubule cytoskeleton, the results suggest a role for the cell wall, or its production machinery, in structuring the microtubule cytoskeleton.

Keywords Cellulose microfibril ordering - Microgravity · Microtubule ordering · Plant cell division - Plant cell growth - Tobacco BY-2 suspension culture cells . TUBUL experiment

$\begin{array}{ll}\text { Abbreviations } \\ 1 g & 1 \times \text { Earth gravity (standard average }=9.8 \mathrm{~m} / \mathrm{s}^{2} \text { ) } \\ \mu g & \text { Near weightlessness } \\ \text { BMM } & \text { Butyl/methyl-methacrylate resin } \\ \text { BSA } & \text { Bovine serum albumin } \\ \text { CLSM } & \text { Confocal laser scanning microscopy } \\ \text { DIC } & \text { Differential interference contrast } \\ \text { ESA } & \text { European Space Agency } \\ \text { FESEM } & \text { Field emission scanning electron microscopy } \\ \text { HMC } & \text { Hoffman modulation contrast } \\ \text { Mes } & 2 \text { - }(N \text {-morpholino)ethanesulfonic acid } \\ \text { PBS } & \text { Phosphate buffered saline } \\ \text { PBU } & \text { Plunger box unit (mini cassette for cell growth) } \\ \text { Pipes } & \text { Piperazine- } N, N^{\prime}-\text { bis }(2-\text {-ethanesulfonic acid) }\end{array}$

\section{Introduction}

Understanding the effects of near weightlessness on the functioning of cells is important for manned space exploration. But above all, questions about the mechanisms of 
gravity sensing by cells are fundamental for understanding the evolution of terrestrial life and address the mechanism of mechanosensory responses and cell polarity development in organisms.

The microtubule cytoskeleton and cell wall play key roles in plant cell growth and division, together determining the final shape of plant cells and therefore the performance of (crop) plants. The relationship between cortical microtubules and cellulose microfibrils, which lie at the opposite sides of the plasma membrane and mechanically determine the elongation axis, is a long-standing question of plant cell growth (Emons et al. 1992; Baskin 2001; Lloyd and Chan 2004). In growing interphase cells, the cortical microtubules are ordered predominantly transverse to the cell's elongation axis. Cellulose synthases (CESA) in etiolated Arabidopsis thaliana hypocotyl cells move bidirectionally in the plasma membrane along tracks that are typically defined by cortical microtubules (Paredez et al. 2006; Emons et al. 2007; Gutierrez et al. 2009). However, examples are known in which, vice versa, cellulose microfibrils impose orientation on newly formed cortical microtubules (Fisher and Cyr 1998; Roberts et al. 2004; Paredez et al. 2008).

The idea for studying these two structural arrays under near weightlessness conditions came from the following observations. In vitro, tubulin self-organizes into parallel microtubule bands, but in near weightlessness (free fall phase of sounding rocket), clinostat-treated and magnetic levitated material (simulated near weightlessness) this pattern is not formed (Papaseit et al. 1999, 2000; Tabony et al. 2002; Portet et al. 2003; Glade et al. 2006; Tabony 2006). In line with these results, it has been reported that in cultured mammalian cells microtubules show altered organizations under real or simulated near weightlessness (experiments on a sounding rocket, parabolic flights, spacecrafts, clinostat, and random positioning machine) (Lewis et al. 1998; Vassy et al. 2001; Lewis 2002; Meloni et al. 2006; Rösner et al. 2006). Also recovering Brassica napus protoplasts (wall-less single plant cells) are affected by real or simulated near weightlessness (experiments on a free-fall machine and on 2D and 3D-clinostats). The microtubule density is temporarily reduced and after 3 days under these conditions, 50\% fewer cells have parallel organized cortical microtubules (Skagen and Iversen 1999). The mitotic index of the recovering protoplasts on the 2D-clinostat was reduced by more than half (Skagen and Iversen 2000). Furthermore, space experiments with $B$. napus protoplasts (Skagen and Iversen 2000) and 2D-clinostat experiments with B. oleracea protoplasts (Nedukha 1998) resulted in reduced cellulose content of the recovering cell wall. Iversen and coworkers conclude that "a unidirectional gravity force is a necessity for the reorganization of cortical microtubules in protoplasts from random to parallel arrays and that cortical microtubules act as responding elements that are able to sense different levels of gravity" (Skagen and Iversen 1999).

On the other hand, whole plants do not show significant changes in growth, flower production, cellulose microfibril ordering, protoxylem and metaxylem vessel element morphology or lignin content when grown in space (Halstead and Dutcher 1987; Musgrave et al. 1997; Levine et al. 2001). Nevertheless, cytological and chemical work indicates there are differences in cell wall texture, thickness, extensibility, and composition and levels of various polysaccharides (Nedukha 1996; Kwon et al. 2001; Soga et al. 2001; Hoson et al. 2003; de Micco et al. 2008). Some of these differences may be due to the lack of convection in plant growth chambers in space, which reduces heat distribution and gas exchange (Musgrave et al. 1997) or other not compensated for effects, such as radiation.

Cell elongation can only be optimal with a fully functional microtubule cytoskeleton. Therefore, we investigated walled, single plant cells growing in an agarose matrix that were exposed to near weightlessness. By using single-walled cells we were able to investigate whether the absence of microtubule ordering should be sought in the cell's behavior in a tissue or in the effect of ordered wall elements and/or their production machinery, e.g., the cellulose synthase complexes. We chose tobacco BY-2 suspension culture cells because the cells in this well-defined system posses robust viability, alternatively grow and divide without interference of differentiation processes, have large cell surfaces to be analyzed for cortical microtubules, and have been used for many plant cell biological studies, especially on the involvement of microtubules in cell elongation and cell division (Nagata et al. 1992; Vos et al. 2004).

The objectives of this study were to determine whether plant cells that are not in a tissue but do have a cell wall elongate and divide as under $1 g$ conditions when cultured for up to 8 days during our TUBUL space flight experiment and to ascertain whether the organization of the cortical microtubule cytoskeleton and the texture of cellulose microfibril wall are maintained at near weightlessness. All imaging and measurements were performed on fixed material since live cell imaging is not yet possible at the ISS. Because we did not find any obvious aberrations in the above characteristics in tobacco BY-2 suspension-culture cells at near weightlessness, we conclude that an organized tissue is not required for cell growth, division, and microtubule and cellulose microfibril organization in space. Possibly, elements of the cell wall, or its production machinery, are involved in organizing the cortical microtubule cytoskeleton. 


\section{Materials and methods}

Space mission

The results described in this manuscript concern our experiment that was part of the $12 \mathrm{~S}$ mission. Plant material (see below) was transported in a portable refrigerator box (Thermocase, Comat Aerospace, Toulouse, France) to Baikonur Cosmodrome, Kazakhstan, 3 days before the launch (see Table 1 for time line). Crew (Pavel Vinogradov, Jeffrey Williams and Marcos Pontes) and integrated samples were launched in Soyuz 12 (TMA-8) on March 29, 2006 9:30 p.m. EST, and transferred to the International Space Station (ISS) shortly after docking on March 31, 2006, 11:19 p.m. EST. After growth and fixation in the ISS, the samples were transferred to Soyuz 11 (TMA-7; Valery Tokarev, William McArthur and Gregory Olsen), which undocked on April 8, 2006, 3:28 p.m. EDT and landed in northern Kazakhstan, near the town of Arkalyk, on April 8,
2006, 7:48 p.m. EDT. Samples, kept at $4^{\circ} \mathrm{C}$ upon landing, were flown to Moscow and from there to Amsterdam. After hardware operation inspection and disassembly of the sample containers at Centre for Concepts in Mechatronics (CCM) in Nuenen, the Netherlands, the samples were transported to our laboratory at Wageningen University for further processing together with the control samples that had remained there.

Detailed descriptions of the tobacco BY-2 suspension culturing and chemical fixation procedures for the space experiments, the experiment hardware and the pre-flight tests and procedures have been published in Sieberer et al. (2007).

Plant material and embedding in agarose

For the experiments, 9-day old Nicotiana tabacum (L.) Bright Yellow-2 suspension cultures (obtained from Ton Timmers, INRA-Toulouse, France) (Nagata et al. 1992),

Table 1 TUBUL-2 experiment time line

\begin{tabular}{|c|c|c|}
\hline $\begin{array}{l}\text { Time in hours before/ } \\
\text { after launch }\end{array}$ & Handling & Temperature \\
\hline-124 to $-120 \mathrm{~h}$ ( -5 days) & $\begin{array}{l}\text { Immobilization of } 9 \text { day old tobacco BY-2 culture in agarose and visual } \\
\text { inspection of quality of cells in laboratory at Wageningen University }\end{array}$ & Room temp $\left(\sim 21^{\circ} \mathrm{C}\right)$ \\
\hline-120 to $-36 \mathrm{~h}$ & $\begin{array}{l}\text { Temperature controlled storage and transport of living cells to Cosmodrome, } \\
\text { Baikonur, Kazakhstan }\end{array}$ & $4^{\circ} \mathrm{C}$ \\
\hline-36 to $-24 \mathrm{~h}$ & $\begin{array}{l}\text { Integration of cultures in PBUs and visual inspection of quality of cells (both } \\
\text { in Wageningen and Baikonur) }\end{array}$ & Room temp \\
\hline-24 to $-18 \mathrm{~h}$ & $\begin{array}{l}\text { Testing and integration of PBUs in the experiment containers and testing of } \\
\text { the hardware by CCM. Integration of experiment containers in control } \\
\text { setup in Wageningen }\end{array}$ & Room temp \\
\hline-18 to $-15 \mathrm{~h}$ & $\begin{array}{l}\text { Testing and integration of experiment containers in the KUBIK incubator by } \\
\text { the mission authorities (European Space Agency (ESA) and Russian } \\
\text { Federal Space Agency (Roscosmos)) }\end{array}$ & Room temp \\
\hline$-15 \mathrm{~h}$ & Power-up of KUBIK incubator in Baikonur and control setup in Wageningen & $21^{\circ} \mathrm{C}$ \\
\hline $0 \mathrm{~h}$ & $\begin{array}{l}\text { Launch of } 12 \mathrm{~S} \text { mission from Cosmodrome Baikonur, Kazakhstan at 30/03/ } \\
2006 \text { 08:30 local time }\end{array}$ & $21^{\circ} \mathrm{C}$ \\
\hline $6 \mathrm{~h}$ & $\begin{array}{l}\text { Fixation in PBU-01 at } \mu g \text { in the Soyuz capsule and in PBU-09 at } 1 g \text { ground } \\
\text { control setup }\end{array}$ & $21^{\circ} \mathrm{C}$ \\
\hline $12 \mathrm{~h}$ & Fixation in PBU-02 at $\mu g$ and in PBU-10 at $1 g$ ground control setup & $21^{\circ} \mathrm{C}$ \\
\hline $84 \mathrm{~h}$ & $\begin{array}{l}\text { Medium refreshment in PBUs that still contain living cells (PBU-03-08) and } \\
\text { ground controls (PBU-11-14) }\end{array}$ & $21^{\circ} \mathrm{C}$ \\
\hline $132 \mathrm{~h}$ (5.5 days) & $\begin{array}{l}\text { Fixation in PBU-03 and } 04 \text { at } \mu g \text { and PBU- } 11 \text { and } 12 \text { at } 1 g \text { ground control } \\
\text { setup }\end{array}$ & $21^{\circ} \mathrm{C}$ \\
\hline 193 h (8 days) & $\begin{array}{l}\text { Fixation in PBU-05 and } 06 \text { at } \mu g \text { and PBU-12 and } 14 \text { at } 1 g \text { ground control } \\
\text { setup. Fixation in PBU-07 and } 08 \text { in the } 1 g \text { on board centrifuge control }\end{array}$ & $21^{\circ} \mathrm{C}$ \\
\hline $210 \mathrm{~h}$ (9 days) & $\begin{array}{l}\text { Removal of all PBUs from KUBIK and stowage in passive stowage pouches } \\
\text { for sample download by Soyuz } 11 \mathrm{~S}\end{array}$ & Ambient temp \\
\hline 240 h (10 days) & Landing of $11 \mathrm{~S}$ mission with TUBUL-2 and other experiment cassettes & Ambient temp \\
\hline $240-288 \mathrm{~h}$ & $\begin{array}{l}\text { Transport from landing site to Moscow in a portable refrigerator box. Storage } \\
\text { of ground control samples in a refrigerator }\end{array}$ & $4^{\circ} \mathrm{C}$ \\
\hline$+288 \mathrm{~h}$ (12 days) & $\begin{array}{l}\text { Inspection of PBUs by CCM, washing and processing of fixed, agarose- } \\
\text { embedded cells (staining, embedding, immunolabeling) }\end{array}$ & $\begin{array}{l}\text { Room temp (unless } \\
\text { otherwise indicated }\end{array}$ \\
\hline
\end{tabular}


which mainly contained large single non-dividing cells, were diluted in warm $\left(29^{\circ} \mathrm{C}\right)$ Murashige-Skoog medium without vitamins, supplemented with $30 \mathrm{~g} / \mathrm{l}$ sucrose, $200 \mathrm{mg} / \mathrm{ml} \quad \mathrm{KH}_{2} \mathrm{PO}_{4}, \quad 100 \mathrm{mg} / \mathrm{ml}$ myo-inositol, $1 \mathrm{mg} / \mathrm{l}$ thiamine and $0.2 \mathrm{mg} / \mathrm{l}$ 2,4-dichlorophenoxyacetic acid (2,4-D) (BY-2 medium) and 1\% low gelling temperature agarose (type VII, BD Bioscience, Poole, UK) at a final cell density of $0.7 \times 10^{6}$ cells $/ \mathrm{ml}$. $8 \mathrm{ml}$ of this culture was poured in $8.4 \mathrm{~cm}$ diameter Petri dishes each containing six $25 \times 12 \mathrm{~mm}$ sterile nylon meshes (gap size $200 \times 200 \mu \mathrm{m})$ and allowed to solidify for $1 \mathrm{~h}$. The nylon mesh was used to reinforce the $1.45 \mathrm{~mm}$ thick agarose layer with cells in the growth compartment. Thereafter, the plates were sealed with Parafilm and kept at $4^{\circ} \mathrm{C}$ in the dark until the start of the experiment time line (see below).

Sample integration and experimental procedure

Starting at $36 \mathrm{~h}$ before launch, the nylon meshes with cells in agarose were transferred to the $25 \mathrm{~mm} \times 10 \mathrm{~mm} \times$ $4 \mathrm{~mm}$ culture chambers of the sterile plunger box units (PBUs; CCM, Nuenen, the Netherlands) (Willemsen and Langerak 2007) as described earlier (Sieberer et al. 2007). We used 6 PBUs for the near weightlessness $(\mu g)$ samples on board the Soyuz and ISS, 2 for the on board $1 g$ centrifuge samples, and another six units for the $1 g$ ground control experiment in our laboratory at Wageningen University. Each PBU contained two independent culture compartments for $\sim 350 \mu \mathrm{l}$ agarose-embedded cells and $\sim 850 \mu \mathrm{l}$ liquid medium, and held $2 \times 3$ additional $1 \mathrm{ml}-$ storage compartments for fully automated medium refreshment, chemical fixation, and a post-fixative wash.
The PBUs were closed with a transparent and gas permeable polyethylene foil and a perforated metal cover and placed in IBE or IBEX type-1 experiment containers (EADS, Immenstaad, Germany). This set-up allowed passive gas exchange with the culture compartments of the PBUs. All handlings were performed equally and at the same time both in Baikonur for the $\mu g$ flight samples and the on-board $1 g$ centrifuge samples, and in Wageningen for the $1 g$ ground control samples. After testing and wiring, the space experiment containers were placed in the temperature-controlled $\left(21^{\circ} \mathrm{C}\right)$ KUBIK incubator (Comat Aerospace, Flourens, France) (van Loon et al. 2007) in which the experiment was carried out, including the $1 g$ centrifuging. The wired ground control containers were placed at $21^{\circ} \mathrm{C}$ in a walk-in climate chamber.

For maintenance of the cell cultures for longer time periods, individual growth compartments of 10 PBUs were flushed with $1 \mathrm{ml} \mathrm{BY-2}$ culture medium $84 \mathrm{~h}$ after launch. At the times indicated in Table 2, BY-2 cells were fixed

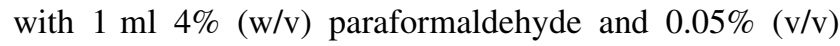
glutaraldehyde in $0.5 \times$ PME buffer $(50 \mathrm{mM}$ piperazine$N, N^{\prime}$-bis(2-ethanesulfonic acid (Pipes), $50 \mathrm{mM}$ EGTA, $5 \mathrm{mM} \mathrm{MgSO}$, $\mathrm{pH}$ 7.0). Fixative release from the storage compartments took $\sim 12 \mathrm{~s}$ and the efficiency of liquid exchange in the growth compartment was $80-85 \%$. Fixed samples were washed with $1 \mathrm{ml} 1 \times$ PME buffer $45 \mathrm{~min}$ after chemical fixation to prevent over-fixation and cytoplasmic extraction. Back in the laboratory at Wageningen University, the fixed cells in agarose were transferred to $4.5 \mathrm{~cm}$ Petri dishes, washed with fresh PME buffer and further processed for DAPI and calcofluor white staining, whole-mount immunolabeling, BMM embedding and immunolabeling, and FESEM.

Table 2 Sample treatments

\begin{tabular}{llllll}
\hline $\begin{array}{l}\text { Experiment } \\
\text { container label }\end{array}$ & $\begin{array}{l}\text { Experiment } \\
\text { container type }\end{array}$ & Position & \multicolumn{2}{l}{ Time of activation after launch } \\
\cline { 3 - 5 } & & & $\begin{array}{l}\text { Medium } \\
\text { exchange }\end{array}$ & Fixation (h) & $\begin{array}{l}\text { Post-fix } \\
\text { wash (h) }\end{array}$ \\
\hline TUB2-01 & IBE & $\mu g$ & - & 6 & $6: 45$ \\
TUB2-02 & IBE & $\mu g$ & - & 12 & $12: 45$ \\
TUB2-03 & IBEX & $\mu g$ & $84 \mathrm{~h}$ & 132 & $132: 45$ \\
TUB2-04 & IBEX & $\mu g$ & $84: 30 \mathrm{~h}$ & $132: 30$ & $133: 15$ \\
TUB2-05 & IBEX & $\mu g$ & $85 \mathrm{~h}$ & 193 & $193: 45$ \\
TUB2-06 & IBEX & $\mu g$ & $86 \mathrm{~h}$ & 194 & $194: 45$ \\
TUB2-07 & IBEX & $1 g$ centrifuge & $85: 30 \mathrm{~h}$ & $193: 30$ & $194: 15$ \\
TUB2-08 & IBEX & $1 g$ centrifuge & $86: 30 \mathrm{~h}$ & $194: 30$ & $195: 15$ \\
TUB2-09 & IBE & $1 g$ ground & - & 6 & $6: 45$ \\
TUB2-10 & IBE & $1 g$ ground & - & 12 & $12: 45$ \\
TUB2-11 & IBEX & $1 g$ ground & $84 \mathrm{~h}$ & 132 & $132: 45$ \\
TUB2-12 & IBEX & $1 g$ ground & $84: 30 \mathrm{~h}$ & $132: 30$ & $133: 15$ \\
TUB2-13 & IBEX & $1 g$ ground & $85 \mathrm{~h}$ & 193 & $193: 45$ \\
TUB2-14 & IBEX & $1 g$ ground & $85: 30 \mathrm{~h}$ & $193: 30$ & $194: 15$ \\
\hline
\end{tabular}


DAPI and calcofluor white staining

For observations of the cyto-architecture and measurements of cell number, size, and mitotic index, $5 \times 5 \mathrm{~mm}$ samples were cut from the nylon meshes with agaroseembedded cells and washed once with phosphate buffered

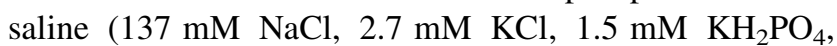
$8.1 \mathrm{mM} \mathrm{Na}_{2} \mathrm{HPO}_{4}, \mathrm{pH}$ 7.4; PBS). For measuring the cell size, cell walls were stained with $0.005 \%(\mathrm{w} / \mathrm{v})$ calcofluor white in PME buffer for $5 \mathrm{~min}$ and washed for $10 \mathrm{~min}$ in $\mathrm{dH}_{2} \mathrm{O}$. To measure the mitotic index, samples were incu-

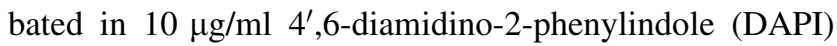
in PBS to label the DNA and washed for $5 \mathrm{~min}$ in PBS. Samples were then mounted between glass slide and cover slip for microscopic observation.

Whole mount immunolocalization

Microtubules were labeled according to a modified protocol (Sieberer et al. 2002; Szechynska-Hebda et al. 2006). Samples of cells in agarose were excised and transferred into glass vials and washed $3 \times 10 \mathrm{~min}$ in PME buffer, followed by a washing-step in $50 \mathrm{mM}$ 2-morpholinoethanesulfonic acid (Mes: pH 6.3) for $10 \mathrm{~min}$. A partial cell wall digestion was carried out in a suspension of $2 \%(\mathrm{w} / \mathrm{v})$ driselase (Fluka, Buchs, Switzerland) and $0.7 \%(\mathrm{w} / \mathrm{v})$ macerozyme-R10 (Serva, Heidelberg, Germany) in $50 \mathrm{mM}$ Mes for $25 \mathrm{~min}$ at $28^{\circ} \mathrm{C}$ on a tilting table. The samples were then washed $2 \times 10 \mathrm{~min}$ in PME buffer and $1 \times 25 \mathrm{~min}$ in PME buffer containing $0.025 \%$ Tween-20. To block unspecific sides, the specimens were incubated for $30 \mathrm{~min}$ in PME buffer containing $1 \%(\mathrm{w} / \mathrm{v})$ bovine serum albumin (BSA) fraction $\mathrm{V}$ and $0.005 \%(\mathrm{v} / \mathrm{v})$ Tween-20. The samples were then incubated in a monoclonal primary antibody to $\alpha$-tubulin, clone DM1 $\alpha$ (Sigma-Aldrich, Zwijndrecht, The Netherlands), diluted 1/300 in PME buffer containing $0.01 \%$ (w/v) acetylated BSA (Aurion, Wageningen, Netherlands), $0.005 \%$ (v/ v) Tween-20 and $0.02 \%(\mathrm{w} / \mathrm{v})$ sodium azide for $3 \mathrm{~h}$ at room temperature. After washing $3 \times 5 \mathrm{~min}$ in PME buffer, the samples were incubated in Alexa 488 conjugated goat antimouse IgG secondary antibody (Molecular Probes, Invitrogen, Carlsbad, CA, USA) diluted 1/300 in PME buffer containing $0.01 \%(\mathrm{w} / \mathrm{v})$ acetylated BSA and $0.005 \%(\mathrm{w} / \mathrm{v})$ Tween-20 for $3 \mathrm{~h}$ at room temperature. Specimens were washed $2 \times 5 \mathrm{~min}$ in PBS and mounted in Citifluor-PBS (Citifluor, London, UK) or PBS containing $0.02 \%(\mathrm{w} / \mathrm{v})$ sodium azide and stored at $4^{\circ} \mathrm{C}$ until observation. During all steps, the cells remained embedded in the agarose.

BMM embedding, sectioning and immunolabeling

Plant material was embedded in butyl/methyl-methacrylate resin (BMM) and immunolabeled according to the protocols by Baskin et al. (1992, 1996). Two pieces of agarose with cells (about $5 \mathrm{~mm} \times 5 \mathrm{~mm}$ ) were cut from each sample and separated from the nylon mesh. After dehydration in increasing concentrations of ethanol $+10 \mathrm{mM}$ dithiothreitol, the material was infiltrated sequentially in 25, 50, 75, and 100\% BMM for $2 \mathrm{~h}$ each step. Individual pieces were placed in freshly prepared BMM in capsules (Beem, West Chester, PA, USA) and polymerized under a UV lamp at $-20^{\circ} \mathrm{C}$ for $24 \mathrm{~h}$.

For immuno labeling, $3 \mu \mathrm{m}$ BMM sections were cut and dried onto slides at $45^{\circ} \mathrm{C}$. After the BMM resin was dissolved in acetone, the sections were subsequently blocked in $0.1 \mathrm{M}$ hydroxylammoniumchloride for $5 \mathrm{~min}$ and in $1 \%$ BSA fraction $\mathrm{V}$ in PBS for $30 \mathrm{~min}$. The material was incubated in primary antibody (1:300 anti-tubulin DM1 $\alpha)$ overnight at $4^{\circ} \mathrm{C}$ and secondary antibody (1:200 GAMAlexa488, Invitrogen) at $37^{\circ} \mathrm{C}$ for $2 \mathrm{~h}$ in $\mathrm{PBS}+0.01 \%$ acetylated BSA. Between all steps the sections were washed in PBS. Labeled sections were enclosed in Citifluor-glycerol (Citifluor, London, UK).

\section{Light microscopy and image processing}

The Petri dishes with agarose-embedded cells were inspected on an inverted Diaphot 200 microscope (Nikon Instruments Europe, Amstelveen, The Netherlands) with Hoffman Modulation Contrast (HMC) system and 20x/0.4 NA and 40x/0.55 NA HMC objectives. Images were recorded with a DXC-95OP CCD camera (Sony, Tokyo, Japan) using real-time digital contrast, low-light enhancement, and background subtraction image processor (Argus20, Hamamatsu Photonics, Hamamatsu City, Japan). At the launch site, samples were observed with a Zeiss Axiovert 40C phase contrast microscope equipped with a LD A-Plan 20x/0.3 NA Ph1 objective (Zeiss, Jena, Germany).

DAPI or calcofluor white-stained cells were imaged on a Zeiss LSM510- META confocal laser scanning microscopy (CLSM) with a 20x/0.5 NA objective and standard DAPI filters after excitation with a 405-nm laser diode. XYZstacks were produced at $512 \times 512$ pixel resolution and $1 \mu \mathrm{m}$ z-steps. Immunolabeled samples (whole mount or BMM embedded sections) were imaged on a Zeiss LSM510-Pascal CLSM with a 63x/1.4 NA objective and standard FITC filters after excitation with the 488-nm laser line of an argon-krypton laser. XYZ-stacks were produced at 512-512 pixel resolution and $1 \mu \mathrm{m}$ z-steps.

To determine cell proliferation, 15 randomly chosen volumes of $0.45 \mathrm{~mm} \times 0.45 \mathrm{~mm} \times 0.1 \mathrm{~mm}$ of DAPIstained cells in agarose from each growth compartment were imaged with CLSM. For each volume, the number of nuclei was determined with the cell counter tool of ImageJ (v1.40 g; W.S. Rasband, United States National Institutes of Health, Bethesda, MD, USA; http://rsb.info.nih.gov/ij/, 
1997-2008). Finally, densities were averaged for each treatment and time point, and fitted to the exponential function: cell density $y=y_{0} \times 2^{(t / \tau)}$ using Origin 7.5 (OriginLab, Northampton, MA, USA) to obtain the doubling time $(\tau)$. The DAPI-labeled image stacks were also used to determine the cell cycle stage of each cell to calculate the mitotic index for each sample. Cell shape was measured from calcofluor white labeled image stacks using the measure tool of ImageJ. Mean cell dimensions were measured as length and width of 37-77 cells per time point and treatment. Bipolar cell elongation was measured as circularity $\left(4 \pi\left(\right.\right.$ area/perimeter $\left.\left.{ }^{2}\right)\right)$ in which a value of 1 means a perfect circle, which translates to a spherical cell.

For image reconstruction of the whole-mount microtubule immunolabeled cells, individual scans of a xyz-series were submitted to a background subtraction algorithm with a rolling point radius of 50 pixels using ImageJ. To obtain a clear view of the cortical MT array, only half of a full Z-series of an entire cell was projected using ImageJ and contrast-enhanced with $0.5 \%$ pixel saturation. Final cropping, resizing and mounting of the images were done with Adobe Photoshop CS2 (Adobe Systems, Mountain View, CA, USA).

\section{Cell wall extraction and FESEM}

The last deposited cellulose microfibrils were visualized according to the protocol by Sugimoto et al. (2003). Cells in agarose were washed in $\mathrm{dH}_{2} \mathrm{O}$ and infiltrated with $12.5 \%$ sucrose for $30 \mathrm{~min}$ and overnight with $25 \%$. Small samples were frozen to specimen holders with Tissue-Tek (Sakura Finetek, Zoeterwoude, The Netherlands) in liquid nitrogen and cut on an Ultracut E cryo-ultramicrotome (ReichertJung, Vienna, Austria) to expose the interior of cells over the whole surface area. By cutting a corner from the agarose sample we maintained the position of the cells relative to the gravity vector in the PBU. After defrosting the samples in $12.5 \%$ sucrose, samples were washed twice in $\mathrm{dH}_{2} \mathrm{O}$ for $15 \mathrm{~min}$ and extracted in $0.1 \%$ sodium hypochlorite for 12 or $15 \mathrm{~min}$. After washing again, samples were dehydrated in a graded ethanol series, followed by two 1:1 ethanol to acetone incubations and two $100 \%$ acetone incubations of $15 \mathrm{~min}$ each. Samples were critical point dried, glued to sample holders with carbon glue, and sputtered with platinum in the antechamber of the SEM (FESEM JEOL 6300F, Tokyo, Japan). The material was imaged at up to $80.000 \times$ magnification.

\section{Results}

For the TUBUL experiments performed during the Dutch DELTA mission in April 2004 and the 12S mission in
March-April 2006, both on board the Soyuz capsule and the International Space Station, we developed a method to culture and chemically fix plant suspension-cultured cells (Sieberer et al. 2007). Tobacco BY-2 cells were immobilized in thin agarose matrices that were reinforced with nylon mesh inside the culture chambers of the fully automated experiment cassettes (Plunger Box Units, PBUs) (Willemsen and Langerak 2007). The PBUs allowed for liquid medium refreshment, passive oxygen supply via a gas-permeable membrane, chemical fixation, and a postfixative wash. Under laboratory conditions, the growth rate of cells in the PBUs was the same as in the agarose matrix covered with a gas permeable cellulose foil in Petri dishes, but delayed and slower than in liquid medium, probably due to the differences in nutrient and oxygen diffusion (Sieberer et al. 2007). Controls for the near weightlessness $(\mu g)$ experiments were not only carried out in the laboratory in Wageningen (referred hereafter as the $1 g$ ground control), but also in a $1 g$ centrifuge inside the same KUBIK incubator as the samples exposed to near weightlessness (referred to as the on-board $1 g$ control). This ensured that observed differences could be attributed to gravity rather than to radiation, vibrations, or other circumstances associated with the flight conditions. Cells were chemically preserved at $6,12,132$ (5.5 days), and $193 \mathrm{~h}$ (8 days) after launch. Due to space limitations only one sample time point $(193 \mathrm{~h})$ was available for the on-board $1 g$ control. Technically, the experiment was $100 \%$ successful; no leakage or other technical failure of the experiment hardware occurred and all experimental steps were executed nominally. From a biological point of view, we had one loss; for unknown reasons in one out of four culture compartments of the flight experiment fixed at $132 \mathrm{~h}$ after launch the cells had not grown. Due to technical problems after the Dutch DELTA mission (Sieberer et al. 2007), we only report results of the TUBUL 2 experiment during the $12 \mathrm{~S}$ mission.

\section{Cell proliferation, size and shape}

Tobacco BY-2 suspension culture cells exposed for up to 8 days to near weightlessness showed similar growth rates compared to the on-board and ground $1 g$ controls (Fig. 1a). Fitting all combined data to an exponential function gave a doubling time of $\sim 80 \mathrm{~h}\left(R^{2}=0.98\right)$. Since the cells had been taken from a non-dividing 9-day-old culture and were stored at $4^{\circ} \mathrm{C}$ until integration starting at $36 \mathrm{~h}$ before launch, the mitotic index was zero at the onset of the experiment time line (Table 1). Thereafter, at $21^{\circ} \mathrm{C}$, the mitotic index quickly increased to its maximum of about $1.2 \%$ at $12 \mathrm{~h}$ after launch and then decreased again to about $0.3 \%$ after 8 days when the nutrients and/or oxygen were most likely near depletion (Fig. 1b). 

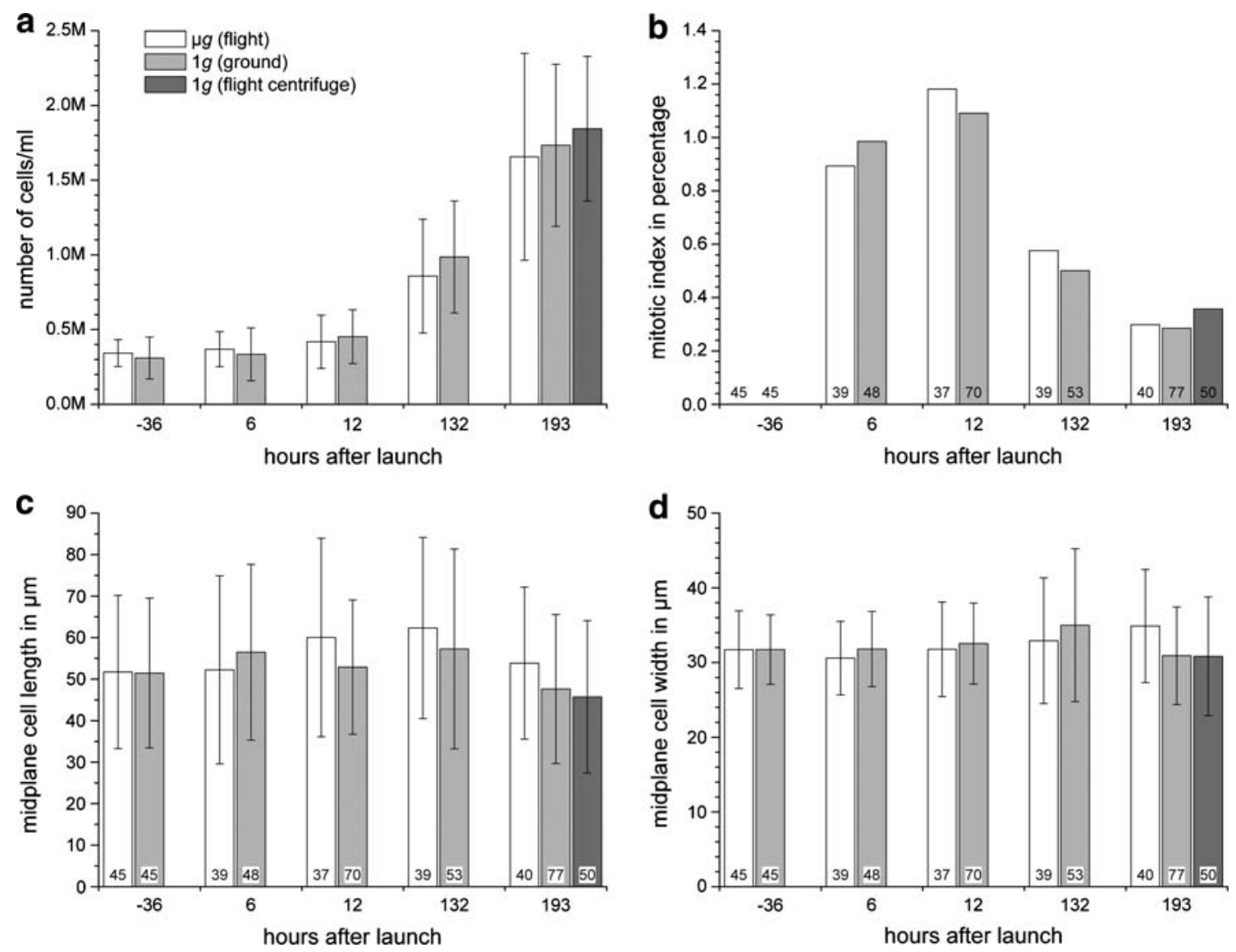

Fig. 1 Cell proliferation and size. Bar graphs representing cell proliferation (a) as the mean of four growth compartments, mitotic index (b) as the total number per counted cells, mean cell length (c) and mean cell diameter (d) for the near weightlessness experiments and the $1 g$ on-board and ground controls. The proliferation was

exponential with a doubling time of around $87 \mathrm{~h}$. The mean cell length and diameter did not statistically differ between the five time points or three gravity treatments. The numbers in the bars represent the number of cells that was measured for calculating the means, error bars represent standard deviation

Tobacco BY-2 suspension cultured cells grow in a diffuse polar fashion, by which they reach an elongated shape. The sizes and shapes of individual cells were measured as length, diameter, and circularity of calcofluor white-stained cell walls from 3-dimensional CLSM images of the cells (see Sect. 2). The average cell length (Fig. 1c), diameter (Fig. 1d), and circularity (data not shown) in near weightlessness did not change in time, and were not statistically different from the ground and onboard $1 g$ control experiments. The mean cell length and diameter were $53 \pm 20$ and $32 \pm 7 \mu \mathrm{m}$, respectively, and the circularity was $0.8 \pm 0.1$ (total means \pm standard deviation; $n=543$ ). All agarose-embedded cell cultures stayed in their appropriate position in the PBUs and hence the directionality of the gravity vector for the $1 g$ samples was known. As expected, cells were elongating at apparently random angles in the agar medium, regardless of the absence or direction of the gravity vector (see Fig. 2a, b).

Cytoarchitecture at the light microscopic level

The interphase cell structure was analyzed with differential interference contrast (DIC) and Hoffman modulation contrast (HMC) microscopy. Figure $2 \mathrm{c}-\mathrm{h}$ shows representative images of the cells at consecutive time points before and after launch. We could not observe differences between cells that were grown under near weightlessness conditions and cells that were grown in the same type of PBUs in our laboratory in Wageningen ( $1 g$ ground control) or the onboard $1 g$ centrifuge. The images show that the tobacco BY2 cells were preserved well with the optimized chemical fixation method. They resembled living cells under comparable culturing conditions (Sieberer et al. 2007). The nucleus of the cells was often located in the center of the cell, and several cytoplasmic strands connected it to the cortical cytoplasm. This typical cytoarchitecture is dependent on the actin cytoskeleton (Hussey et al. 2006; van der Honing et al. 2007), but we were not able to visualize actin 

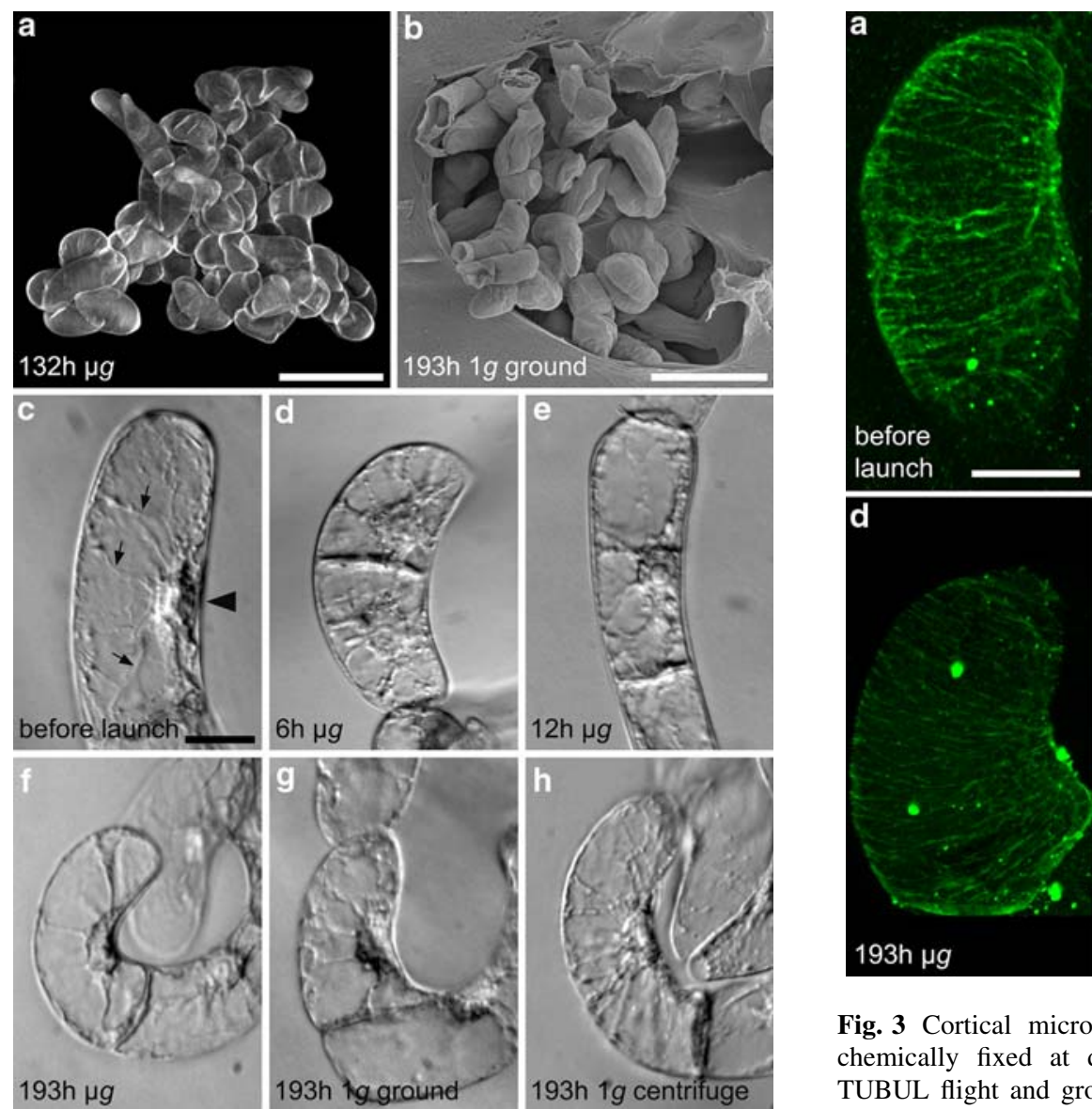

Fig. 2 Overview and cytoarchitecture of BY-2 cells that were chemically fixed at different time-points of the TUBUL flight and ground experiments. a Projection of an image stack of a calcofluor white stained cell cluster fixed after 5 days at near weightlessness and imaged with CLSM. The cells elongated and divided in all directions, independently of the direction of gravity. b FESEM micrograph of a cell cluster fixed after 8 days at $1 g$ on Earth. c Cytoarchitecture of an interphase cell fixed $36 \mathrm{~h}$ before rocket launch. The samples in (d-f) were exposed to near weightlessness for $6 \mathrm{~h}(\mathbf{d}), 12 \mathrm{~h}(\mathbf{e})$ and $193 \mathrm{~h}$ (f). The samples in $\mathbf{g}$ and $\mathbf{h}$ were exposed to $1 \mathrm{~g}$ for $193 \mathrm{~h}$ on Earth (g) or in the on-board $1 g$ centrifuge (h). The cells do not show obvious fixation artifacts; the thin cytoplasmic strands (arrows in c) radiating from the nucleus (arrowhead in c), and the cortical cytoplasm and outer membrane are well preserved. Furthermore, there are no evident differences in cytoarchitecture between the $\mu g$ and $1 g$ samples. The direction of the gravity vector in panels $\mathbf{b}, \mathbf{g}$ and $\mathbf{h}$ is perpendicular to the field of view. The microbars in $\mathbf{a}$ and $\mathbf{b}$ are $100 \mu \mathrm{m}$; the microbar in $\mathbf{c}$ for the remaining panels is $20 \mu \mathrm{m}$

filaments or bundles with fluorescent phalloidin staining or immunocytochemistry.

\section{Microtubule organization}

The cortical microtubule organization in interphase cells exposed to near weightlessness was indistinguishable from control cells on Earth ( $1 \mathrm{~g}$ ground control) and in space (onboard $1 g$ centrifuge) in terms of (bundle) density, ordering
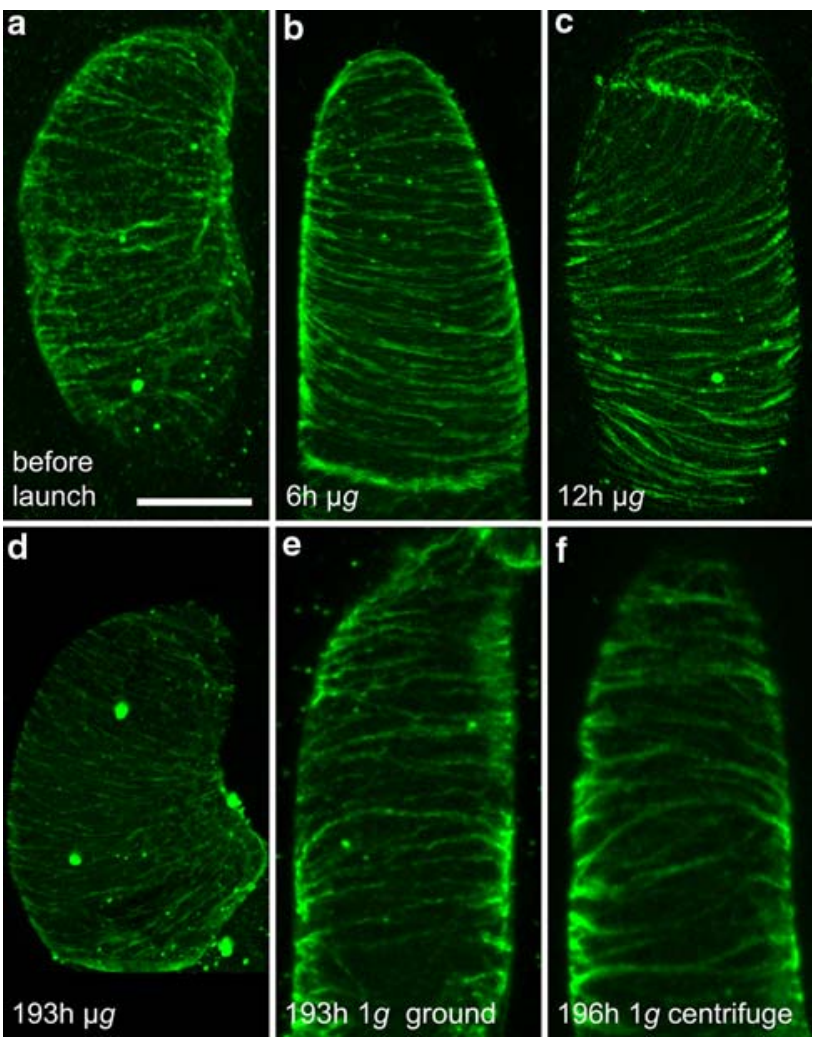

Fig. 3 Cortical microtubules in interphase BY-2 cells that were chemically fixed at different time-points before and during the TUBUL flight and ground experiments. Cortical microtubules were labeled by whole-mount immunocytochemistry and visualized with CLSM at scanning steps of $1 \mu \mathrm{m}$. Microtubule arrays are presented as half-stack projections. a Cell fixed $36 \mathrm{~h}$ before rocket launch. Samples in (b-d) were exposed to near weightlessness for $6 \mathrm{~h}(\mathbf{b})$, $12 \mathrm{~h} \mathrm{(c)} \mathrm{and} 193 \mathrm{~h} \mathrm{(d).} \mathrm{Samples} \mathrm{in} \mathrm{e} \mathrm{and} \mathrm{f} \mathrm{were} \mathrm{exposed} \mathrm{to} 1 \mathrm{~g}$ for $193 \mathrm{~h}$ on Earth (e) or the on-board centrifuge (f). Cortical microtubules are present in all cells and their overall patterning is in parallel bundles, oriented transversely to the long axis of the cell. There are no obvious (qualitative) differences in microtubule orientation and density between cells exposed to $\mu g$ or $1 g$. Magnification is the same in all images. The microbar is $50 \mu \mathrm{m}$ for all panels

and overall orientation in a qualitative analysis. Cortical microtubule organization was similar to the organization in cells $36 \mathrm{~h}$ prior to launch. There were also no differences visible between cells of the two controls. This result corroborates our results on cell shape that showed that cells acquired similar lengths and widths under the three test conditions. Figure 3 shows representative examples of whole mount preparations of immunolabeled cortical microtubules of cells grown under near weightlessness conditions and in the $1 \mathrm{~g}$ ground and on-board controls. Similar results were found for immunolabeled BMM embedded sections (data not shown).

\section{Cellulose microfibril organization}

Microtubule orientation may determine the orientation of cellulose microfibrils during their deposition which then 

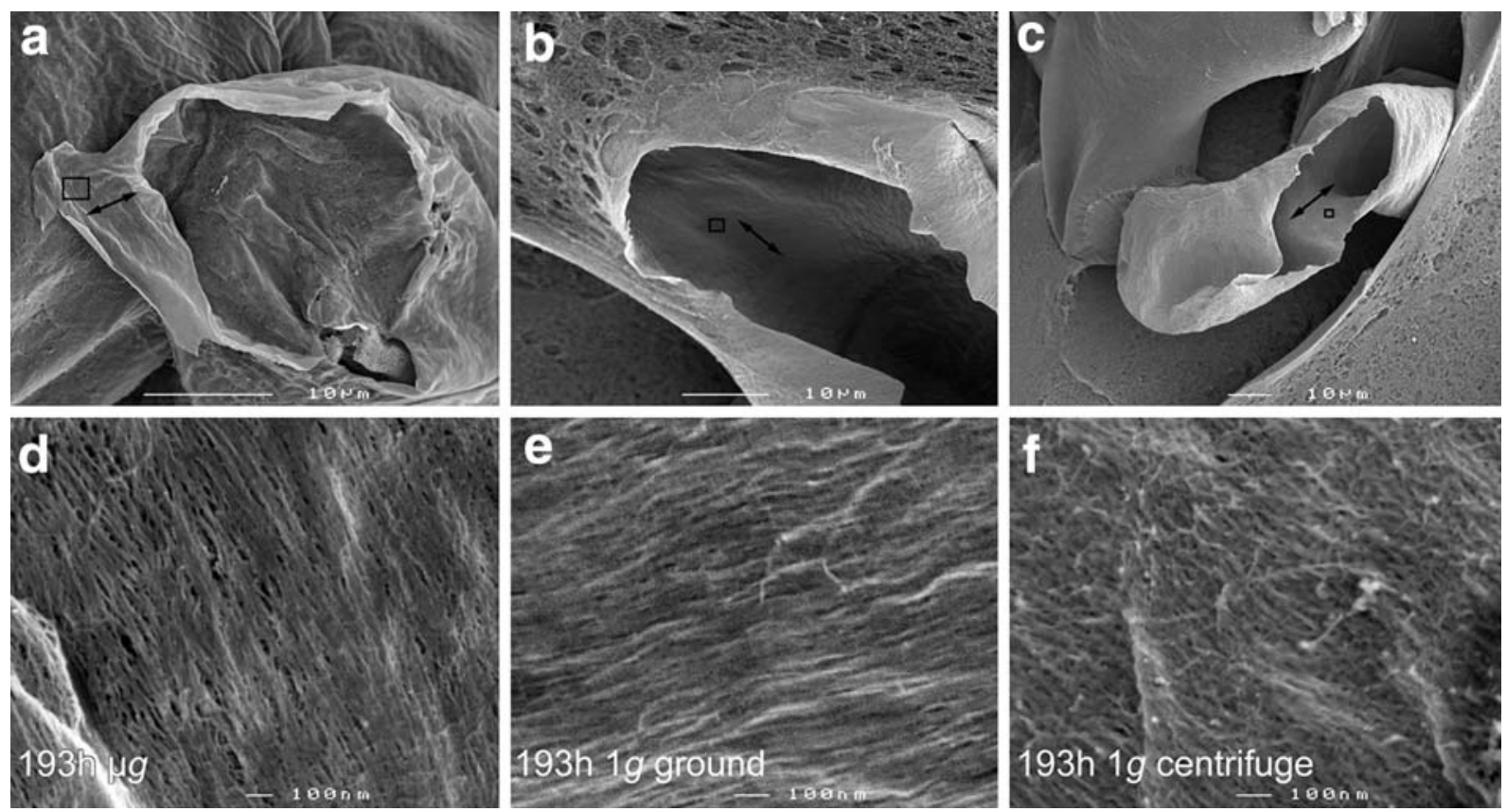

Fig. 4 FESEM of the cell walls, comparing near weightlessness versus $1 g$ conditions. Representative micrographs show the last deposited cellulose microfibrils after hypochlorite extraction of the cell content and cryo-sectioning of tobacco BY-2 cells grown for 8 days at near weightlessness (a and d), in the $1 g$ ground control PBUs (b and e) and the on-board $1 g$ control PBUs (c and f). The top row gives an overview of the cell that has been cut open; the bottom

determines the cell elongation axis. Using scanning electron microscopy, we determined the orientation of the innermost, i.e., last deposited cellulose microfibrils of the cell walls of interphase cells according to a protocol adapted from (Sugimoto et al. 2000). We found no effect of near weightlessness on the orientation of cellulose microfibril deposition, which was transverse to the longitudinal cell axis, i.e., the predicted elongation direction, in all observed cells after 8 days under all three experimental conditions (Fig. $4 ; n=9$ cells for $\mu g, 7$ cells for the $1 g$ ground control and six cells for the on-board $1 g$ control).

\section{Discussion}

As microtubule organization, both in vitro (Tabony et al. 2002) and in regenerating protoplasts (Skagen and Iversen 1999) were shown to be hampered at reduced gravity, we set out to investigate the influence of gravity on microtubule organization, cell wall texture, cell elongation, and cell shape, in single, walled plant cells. We found that at near weightlessness during an 8-day space experiment, tobacco BY-2 suspension culture cells divided and grew as the control cells in the on-board $1 \mathrm{~g}$ centrifuge and the $1 \mathrm{~g}$ ground setup. Their interphase cytoarchitecture and their row gives a detail of the cellulose microfibrils in the area indicated with a black box in the top row micrographs. The last deposited cellulose microfibrils are aligned transverse to the cell's longitudinal axis under all three experimental conditions (longitudinal cell axis indicated with arrows). The microbars are $10 \mu \mathrm{m}(\mathbf{a}-\mathbf{c})$ and $100 \mathrm{~nm}$ $(\mathbf{d}, \mathbf{e})$

cortical microtubule and cellulose microfibril ordering were also indistinguishable. Not only did near weightlessness not alter these characteristics, the whole environment, including radiation and vibrations, also did not affect the processes that are crucial for plant cell growth and proliferation. These are important and positive results if, in the future, plants have to be propagated from (frozen) cell culture stocks during long-term space missions. In general, our results agree with several studies using whole plants (Halstead and Dutcher 1987; Musgrave et al. 1997; Levine et al. 2001), but contrast with the findings of Sato and coworkers (1999), who reported, based on electron microscopic observations, that Nicotiana tabacum stem explants grown in space had reduced microtubule quantities. We conclude that plant cells do not need to be organized in a tissue to grow, divide and organize their microtubules and cellulose microfibrils in space.

Gravity is a mechanical force acting on Earth in one direction, which we counter in free-fall experiments. Although weak, this force has been shown to influence cells that are not specialized in gravisensing (Lewis 2002; Loesberg et al. 2008). The first change in a gravitational biological experiment is a mechanical change; all other changes depend on it and are subsequent (van Loon 2007b). Physics models show that for a mechanical effect, 
the sedimentation of the gravity-sensing element must outweigh diffusion and Brownian motion (Portet et al. 2003). Microtubules can function as these sedimenting mechano-sensing elements (Tabony et al. 2007). However, unlike the direct link between gravity and microtubule ordering in polymerization experiments in vitro, there does not seem to be a correlation between the direction of gravity and the direction of cell elongation in the agaroseembedded non-differentiating tobacco BY-2 cell clusters (Fig. 2a, b).

The combined results of the protoplast experiments by Skagen and Iversen $(1999,2000)$ and our suspension cell experiments may point to a mechanism in which the cell wall offers signals, or mechanical or spatial cues that facilitate cortical microtubule orientation as has been proposed before (Emons et al. 1992; Fisher and Cyr 1998; Baskin 2001; Paredez et al. 2006; Chu et al. 2007; Paredez et al. 2008). Protoplasts have no walls and do not experience the influence of cell shape (Cosentino Lagomarsino et al. 2007; Terenna et al. 2008), mechanical stress (Hamant et al. 2008) or cell wall texture (Fisher and Cyr 1998). Cyr and coworkers (therefore) proposed that biophysical anisotropic strain of the cell wall is essential for setting up microtubule ordering and cell elongation (Wymer et al. 1996a, b; Fisher and Cyr 1998). So, only when the cell wall is absent, does gravity become influential to align the cortical microtubules (Skagen and Iversen 1999, 2000). This notion is underpinned by the effect of weightlessness on the microtubule cytoskeleton in animal cells (Lewis et al. 1998; Vassy et al. 2001; Lewis 2002; Meloni et al. 2006; Rösner et al. 2006). Our preliminary results using a random positioning machine also indicate that microtubule ordering and cell elongation are initially delayed in tobacco BY-2 protoplasts (Oudenhoven et al. unpublished results). The bidirectional flow of information between the cell wall and microtubule array could be accomplished by the cellulose microfibrils proper or the cellulose synthase complexes, that partly travel in the same pseudo $2 \mathrm{D}$ space along the plasma membrane as the microtubules, since deletion of CESA2 or mutation of CESA6 both cause disordered microtubule arrays (Chu et al. 2007; Paredez et al. 2008).

It is generally believed that cell elongation needs parallel aligned cellulose microfibrils transverse to the elongation direction, which, at its turn, needs parallel aligned microtubules. Microtubules could be aligned by cues from an anisodiametric cell shape, anisotropical mechanical stress, moving cellulose synthase complexes, a pre-existing cell wall pattern, or maybe gravity. So, in combination with the use of protoplasts, mutants, and microtubule and cellulose microfibril inhibitors, near weightlessness is an experimental tool to further investigate the orientation mechanism of these two polymers at both sides of the plasma membrane. The question currently under investigation in our laboratory is if recovering protoplasts (i.e., cells without pre-existing wall) at simulated near weightlessness can order their cellulose microfibrils in the absence of microtubules, and vice versa, if recovering protoplasts can order their microtubules in the absence of cellulose microfibril production. Space flight experiments are technically and logistically demanding (and very expensive). Fortunately, it is possible to approximate this type of biological experiments on a random positioning machine in which a state of functional near weightlessness may be simulated by constantly and randomly changing the direction of the gravity vector (Hoson et al. 1997; Kraft et al. 2000; van Loon 2007a). Such experiments also have the advantage that short-term studies can be done and gravity sensing can be studied separately from the cell's adaptation to gravity.

Acknowledgments We thank Marike Cusell for technical assistance and cell culturing during the first TUBUL flight experiment, Dr. Jack van Loon (Dutch Experiment Support Center, Vrije Universiteit, Amsterdam, The Netherlands) for advice with administrative tasks, stimulating discussions and critically reading the manuscript, and Antoon Koppen and Edwin Langerak of CCM in Nuenen, the Netherlands, for their collaboration and production of the flight hardware. This project was funded by the Netherlands Institute for Space Research (SRON), project numbers MG-061 and GO-MG/01, and in part by a NWO VENI grant (863.02.009) to JWV. We thank the Dutch government and ESA for making the TUBUL experiments possible, for logistics and for financial and technical support.

Open Access This article is distributed under the terms of the Creative Commons Attribution Noncommercial License which permits any noncommercial use, distribution, and reproduction in any medium, provided the original author(s) and source are credited.

\section{References}

Baskin TI (2001) On the alignment of cellulose microfibrils by cortical microtubules: a review and a model. Protoplasma 215:150-171

Baskin TI, Busby CH, Fowke LC, Sammut M, Gubler F (1992) Improvements in immunostaining samples embedded in methacrylate: localization of microtubules and other antigens throughout developing organs in plants of diverse taxa. Planta 187:405-413

Baskin TI, Miller DD, Vos JW, Wilson JE, Hepler PK (1996) Cryofixing single cells and multicellular specimens enhances structure and immunocytochemistry for light microscopy. J Microsc (Oxf) 182:149-161

Chu Z, Chen H, Zhang Y, Zhang Z, Zheng N, Yin B, Yan H, Zhu L, Zhao X, Yuan M, Zhang X, Xie Q (2007) Knockout of the AtCESA2 gene affects microtubule orientation and causes abnormal cell expansion in Arabidopsis. Plant Physiol $143: 213-224$

Cosentino Lagomarsino M, Tanase C, Vos JW, Emons AMC, Mulder BM, Dogterom M (2007) Microtubule organization in threedimensional confined geometries: evaluating the role of elasticity through a combined in vitro and modeling approach. Biophys J 92:1046-1057 
de Micco V, Aronne G, Joseleau JP, Ruel K (2008) Xylem development and cell wall changes of soybean seedlings grown in Space. Ann Bot (Lond) 101:661-669

Emons AMC, Derksen J, Sassen MMA (1992) Do microtubules orient plant-cell wall microfibrils? Physiol Plant 84:486-493

Emons AMC, Hofte H, Mulder BM (2007) Microtubules and cellulose microfibrils: how intimate is their relationship? Trends Plant Sci 12:279-281

Fisher DD, Cyr RJ (1998) Extending the microtubule/microfibril paradigm. Cellulose synthesis is required for normal cortical microtubule alignment in elongating cells. Plant Physiol 116:1043-1051

Glade N, Beaugnon E, Tabony J (2006) Ground-based methods reproduce space-flight experiments and show that weak vibrations trigger microtubule self-organisation. Biophys Chem 121:1-6

Gutierrez R, Lindeboom JJ, Paredez AR, Emons AMC, Ehrhardt DW (2009) Arabidopsis cortical microtubules position cellulose synthase delivery to the plasma membrane and interact with cellulose synthase trafficking compartments. Nat Cell Biol 11:797-806

Halstead TW, Dutcher FR (1987) Plants in space. Annu Rev Plant Physiol 38:317-345

Hamant O, Heisler MG, Jonsson H, Krupinski P, Uyttewaal M, Bokov P, Corson F, Sahlin P, Boudaoud A, Meyerowitz EM, Couder Y, Traas J (2008) Developmental patterning by mechanical signals in Arabidopsis. Science 322:1650-1655

Hoson T, Kamisaka S, Masuda Y, Yamashita M, Buchen B (1997) Evaluation of the three-dimensional clinostat as a simulator of weightlessness. Planta 203:S187-S197

Hoson T, Soga K, Wakabayashi K, Kamisaka S, Tanimoto E (2003) Growth and cell wall changes in rice roots during spaceflight. Plant Soil 255:19-26

Hussey PJ, Ketelaar T, Deeks MJ (2006) Control of the actin cytoskeleton in plant cell growth. Annu Rev Plant Biol $57: 109-125$

Kraft TF, van Loon JJ, Kiss JZ (2000) Plastid position in Arabidopsis columella cells is similar in microgravity and on a randompositioning machine. Planta 211:415-422

Kwon M, Bedgar DL, Piastuch W, Davin LB, Lewis NG (2001) Induced compression wood formation in Douglas fir (Pseudotsuga menziesii) in microgravity. Phytochemistry 57:847-857

Levine LH, Heyenga AG, Levine HG, Choi J, Davin LB, Krikorian AD, Lewis NG (2001) Cell-wall architecture and lignin composition of wheat developed in a microgravity environment. Phytochemistry 57:835-846

Lewis ML (2002) The cytoskeleton, apoptosis, and gene expression in $\mathrm{T}$ lymphocytes and other mammalian cells exposed to altered gravity. In: Cogoli A (ed) Cell biology and biotechnology in space. Elsevier, Amsterdam, pp 77-128

Lewis ML, Reynolds JL, Cubano LA, Hatton JP, Lawless BD, Piepmeier EH (1998) Spaceflight alters microtubules and increases apoptosis in human lymphocytes (Jurkat). FASEB J 12:1007-1018

Lloyd C, Chan J (2004) Microtubules and the shape of plants to come. Nat Rev Mol Cell Biol 5:13-23

Loesberg WA, Walboomers XF, van Loon JJ, Jansen JA (2008) Simulated microgravity activates MAPK pathways in fibroblasts cultured on microgrooved surface topography. Cell Motil Cytoskeleton 65:116-129

Meloni MA, Galleri G, Pippia P, Cogoli-Greuter M (2006) Cytoskeleton changes and impaired motility of monocytes at modelled low gravity. Protoplasma 229:243-249

Musgrave ME, Kuang A, Matthews SW (1997) Plant reproduction during spaceflight: importance of the gaseous environment. Planta 203:S177-S184
Nagata T, Nemoto Y, Hasezawa S (1992) Tobacco BY-2 cell line as the "HeLa" cell in the cell biology of higher plants. Int Rev Cytol 132:1-30

Nedukha EM (1996) Possible mechanisms of plant cell wall changes at microgravity. Adv Space Res 17:37-45

Nedukha EM (1998) Effects of clinorotation on the polysaccharide content of resynthesized walls of protoplasts. Adv Space Res 21:1121-1126

Papaseit C, Vuillard L, Tabony J (1999) Reaction-diffusion microtubule concentration patterns occur during biological morphogenesis. Biophys Chem 79:33-39

Papaseit C, Pochon N, Tabony J (2000) Microtubule self-organization is gravity-dependent. Proc Natl Acad Sci USA 97:8364-8368

Paredez AR, Somerville CR, Ehrhardt DW (2006) Visualization of cellulose synthase demonstrates functional association with microtubules. Science 312:1491-1495

Paredez AR, Persson S, Ehrhardt DW, Somerville CR (2008) Genetic evidence that cellulose synthase activity influences microtubule cortical array organization. Plant Physiol 147:1723-1734

Portet S, Tuszynski JA, Dixon JM, Sataric MV (2003) Models of spatial and orientational self-organization of microtubules under the influence of gravitational fields. Phys Rev E Stat Nonlin Soft Matter Phys 68:021903-1-021903-9

Roberts AW, Frost AO, Roberts EM, Haigler CH (2004) Roles of microtubules and cellulose microfibril assembly in the localization of secondary-cell-wall deposition in developing tracheary elements. Protoplasma 224:217-229

Rösner H, Wassermann T, Möller W, Hanke W (2006) Effects of altered gravity on the actin and microtubule cytoskeleton of human SH-SY5Y neuroblastoma cells. Protoplasma 229:225-234

Sieberer BJ, Timmers ACJ, Lhuissier FGP, Emons AMC (2002) Endoplasmic microtubules configure the subapical cytoplasm and are required for fast growth of Medicago truncatula root hairs. Plant Physiol 130:977-988

Sieberer BJ, Emons AMC, Vos JW (2007) Culturing immobilized plant cells for the TUBUL space experiments on the DELTA and 12S Missions. Microgravity Sci Technol 19:45-49

Skagen EB, Iversen TH (1999) Simulated weightlessness and hyper-g results in opposite effects on the regeneration of the cortical microtubule array in protoplasts from Brassica napus hypocotyls. Physiol Plant 106:318-325

Skagen EB, Iversen TH (2000) Effect of simulated and real weightlessness on early regeneration stages of Brassica napus protoplasts. In Vitro Cell Dev Biol Plant 36:312-318

Soga K, Wakabayashi K, Hoson T, Kamisaka S (2001) Gravitational force regulates elongation growth of Arabidopsis hypocotyls by modifying xyloglucan metabolism. Adv Space Res 27:1011-1016

Sugimoto K, Williamson RE, Wasteneys GO (2000) New techniques enable comparative analysis of microtubule orientation, wall texture, and growth rate in intact roots of Arabidopsis. Plant Physiol 124:1493-1506

Sugimoto K, Himmelspach R, Williamson RE, Wasteneys GO (2003) Mutation or drug-dependent microtubule disruption causes radial swelling without altering parallel cellulose microfibril deposition in arabidopsis root cells. Plant Cell 15:1945

Szechynska-Hebda M, Wedzony M, Dubas E, Kieft H, van Lammeren A (2006) Visualisation of microtubules and actin filaments in fixed BY-2 suspension cells using an optimised whole mount immunolabelling protocol. Plant Cell Rep 25:758-766

Tabony J (2006) Microtubules viewed as molecular ant colonies. Biol Cell 98:603-617

Tabony J, Glade N, Papaseit C, Demongeot J (2002) Microtubule self-organisation and its gravity dependence. In: Cogoli A (ed) Cell biology and biotechnology in space. Elsevier, Amsterdam, pp 19-58 
Tabony J, Rigotti N, Glade N, Cortès S (2007) Effect of weightlessness on colloidal particle transport and segregation in selforganising microtubule preparations. Biophys Chem 127: $172-180$

Terenna CR, Makushok T, Velve-Casquillas G, Baigl D, Chen Y, Bornens M, Paoletti A, Piel M, Tran PT (2008) Physical mechanisms redirecting cell polarity and cell shape in fission yeast. Curr Biol 18:1748-1753

van der Honing HS, Emons AM, Ketelaar T (2007) Actin based processes that could determine the cytoplasmic architecture of plant cells. Biochim Biophys Acta 1773:604-614

van Loon JJWA (2007a) Some history and use of the random positioning machine, RPM, in gravity related research. Adv Space Res 39:1161-1165

van Loon JJWA (2007b) Micro-gravity and mechanomics. Gravit Space Biol 20:3-18

van Loon JWA, Medina FJ, Stenuit H, Istasse E, Heppener M, Marco R (2007) The national-ESA Soyuz missions Andromède, Marco Polo, Odissea, Cervantes, Delta and Eneide. Microgravity Sci Technol 19:9-32
Vassy J, Portet S, Beil M, Millot G, Fauvel-Lafeve F, Karniguian A, Gasset G, Irinopoulou T, Calvo F, Rigaut JP, Schoevaert D (2001) The effect of weightlessness on cytoskeleton architecture and proliferation of human breast cancer cell line MCF-7. FASEB J 15:1104-1106

Vos JW, Dogterom M, Emons AM (2004) Microtubules become more dynamic but not shorter during preprophase band formation: a possible "search-and-capture" mechanism for microtubule translocation. Cell Motil Cytoskeleton 57:246-258

Willemsen H, Langerak E (2007) Hardware for biological microgravity experiments in Soyuz missions. Microgravity Sci Technol 19:75-79

Wymer CL, Fisher DD, Moore RC, Cyr RJ (1996a) Elucidating the mechanism of cortical microtubule reorientation in plant cells. Cell Motil Cytoskeleton 35:162-173

Wymer CL, Wymer SA, Cosgrove DJ, Cyr RJ (1996b) Plant cell growth responds to external forces and the response requires intact microtubules. Plant Physiol 110:425-430 